\title{
Extinct and endangered archaeophytes and the dynamics of their diversity in Poland
}

\author{
Maria Zając ${ }^{1 *}$, Adam Zając ${ }^{1} \&$ Barbara Tokarska-Guzik²
}

${ }^{1}$ Institute of Botany, Jagiellonian University, Kopernika 27, 31-501 Kraków, Poland, *e-mail: zajacm@ib.uj.edu.pl

${ }^{2}$ Department of Plant Systematics, Faculty of Biology and Environmental Protection, University of Silesia, Jagiellońska 28, 40-032 Katowice, Poland

\begin{abstract}
A full list of extinct and endangered archaeophyte species for Poland is presented according to IUCN categories. The species are analysed in respect of their origin and syntaxonomic classification. Endangered archaeophytes should be cultivated in botanical gardens and open-air museums, and next reintroduced to natural sites.
\end{abstract}

Keywords: archaeophytes, archaeophyta anthropogena, endangered species, plant origin, origin of archaeophytes, Poland

\section{Introduction}

Archaeophytes are alien plant species that have been introduced to a region before the discovery of America. Thus they are a group of old anthropophytes (i.e. plants accompanying humans), distinguished within the floras of Europe. In Poland, the oldest among them appeared with the onset of Neolithic agriculture. Several hypotheses on their origin have been presented, some of them well-documented more, some less so (Zając 1979). They are segetal (i.e. field weeds) or ruderal plants. Many of them have adapted to traditional methods of cultivation or to specific ruderal habitats. The changing techniques of cultivation, preparation of seeds for sowing, and the disappearance of old ruderal habitats, brought about the massive disappearance of these plants. A significant proportion of species classified in this group are identified as threatened to various degrees. The extinction of these species would impoverish the biodiversity of our flora. Thus it is necessary to undertake measures that can save this group of vascular plants, both within the borders of various countries and within the European context. In many European countries these species have become extinct, as indicated in red lists and red data books especially for Central and Northern Europe (i.e. Čeřovský et al. 1999; Kotiranta et al. 1998; Niklfeld 1999; Ludwig \& Schnittler 1996).

\section{Material and methods}

The term "archaeophyte" is rather clearly defined in the European literature (Kornaś \& Medwecka-Kornaś 2002; Kukkonen 1995; Scholz 1995). It is impossible to prepare a list of archaeophytes for the whole territory of Europe, or even for Central Europe; it is possible only for individual countries. In this study, we used the list of archaeophytes for Poland published and next updated by Zając (1983, 1987a, 1987b, 1988), later verified by Zając et al. (1998). This list, since its first publication, has been changed and supplemented in relation to our growing knowledge about alien plants in Poland.

To assess the threat for particular species, we used data from the ATPOL database (Zajac 1978) and cartogram maps (Zając A. \& Zając M. 2001). More recent floristic records have been also obtained from published and unpublished sources gathered by other botanists.

In the Polish Plant Red Data Book (Kaźmierczakowa \& Zarzycki 2001), 6 species of archaeophytes were included, but in the "Red List of Vascular Plants in Poland" (Zarzycki \& Szelag 2006), their number reached 34 species. In comparison with the latter publication, the present paper includes major changes in classifying species to particular categories of threat (IUCN 1994). 
We follow the classification used by Kaźmierczakowa \& Zarzycki (2001). The most useful category was DD (Data Deficient), which includes species with still insufficient data, but which should be regarded as threatened.

\section{Results}

\subsection{The red list of archaeophytes in Poland}

In Poland, some 165 species are regarded as archaeophytes. Out of this number, 74 taxa, representing ca. $44.8 \%$ of the total, are classified as extinct or more or less threatened (Appendix, Fig. 1). It is a significant proportion, much higher than indicated for native components of the flora (21\%, Zarzycki \& Szelag 2006). Five species have become extinct in the territory of Poland (5 taxa). However, they have suffered a similar fate throughout their distribution area. More taxa are critically endangered (13 species): they occur only in very few stations and are disappearing throughout their historical distribution range. At the stations where they still occur, their numbers are low, so if special measures are not taken, they will probably be soon classified as extinct. Endangered taxa (16 species) are a group with a high probability of becoming extinct, but over a longer time horizon. These species have already lost most of their historical habitats, but still occur in many stations and in populations numerous enough to be saved by humans without major efforts. The largest group are vulnerable taxa (31 species). They are evidently in retreat, but still have a fairly high number of stations, at least in some areas. Many of these species die out at the fringes of their distribution ranges, or become less frequent throughout their previous ranges (this pertains to the species that do not have evident limits of distribution

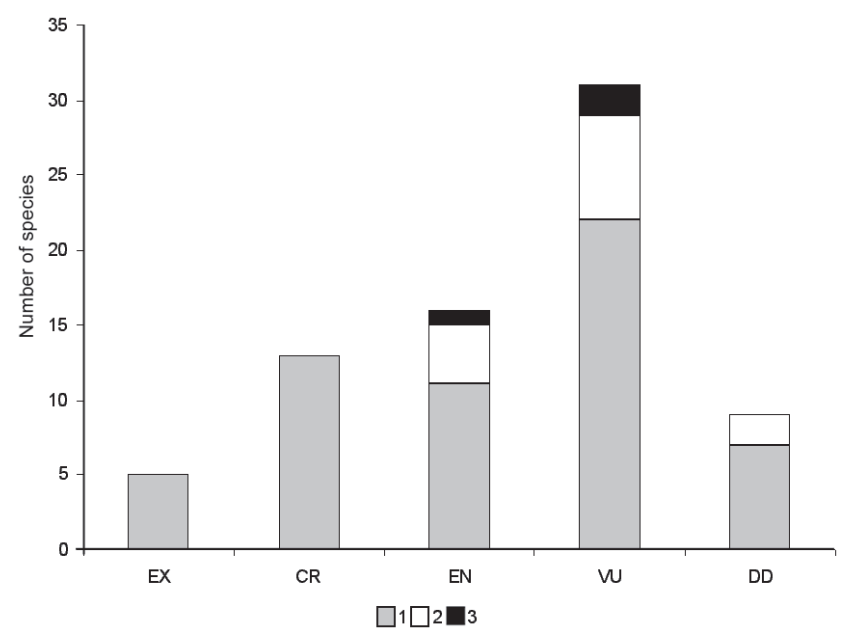

Fig. 1. Numbers of archaeophyte species extinct and threatened with extinction in Poland

Explanations: EX - extinct, $\mathrm{CR}$ - critically endangered, EN - endangered, VU - vulnerable, DD - data deficient, 1 - only segetal, 2 - only ruderal, 3 both segetal and ruderal within the territory of Poland). Nine species were classified as facing minor risk. This group includes the taxa for which the level of risk has not been established yet (because they are often not distinguished from their close relatives, e.g. Aphanes microcarpa) or those whose satisfactory status is a temporary condition (e.g. Avena strigosa, which could come under pressure of extinction soon after agricultural practices change).

This high proportion of species of archaeophytes classified under IUCN categories indicates that in Poland this historical/geographical group of synanthropic taxa is among those most endangered. Taking into consideration how this group, unlike any other, is affected by human economic activities, it should be the focus of attention and be specially protected by the society.

\subsection{Origin of threatened species}

Archaeophytes arrived in Poland often in distant past and not directly from their homelands, but in stages, as they accompanied the Neolithic people who gradually colonized more distant and less suitable areas of Europe. It is difficult to determine what kind of threat to their existence they face in their hypothetical homelands. For the archaeophytes occurring in Poland, the hypotheses regarding their origin have been presented in a number of publications (Zając 1983, 1987a, 1987b, 1988). These species come from geographically diverse areas. Their hypothetical areas of origin (Appendix), in the case of segetal weeds, only partly overlap with the areas of primary natural occurrence of wild species of cereals (the Fertile Crescent). Most often these are species that became weeds in the areas of secondary extension of cultivated lands, by the migration of early agricultural peoples into Central Europe. Homelands of those plants are often identified as a large region, such as the entire Mediterranean subkingdom or Irano-Turanian subkingdom, or these species originally were a part of the Mediterranean-Irano-Turanian connecting element. The archaeophytes occurring in ruderal sites also have a very broad spectrum of areas where they most probably occur as native species. Taking into consideration the areas from where the subsequent migration waves of peoples settling in Central Europe arrived, this approach is fully justified.

An essential group among archaeophytes are those classified as archaeophyta anthropogena (Mirek 1981). These are taxa that have evolved owing to humans. In Poland, 21 such species occur, and our list includes as many as 18 of them. These are taxa that have been selected by humans from natural populations growing within Poland, such as Rhinanthus alecterolophus subsp. bucalis, $R$. serotinus subsp. apterus, and Odontites verna. The evolution of their diaspores has lead to ever closer likeness to the grains of the caryopsis of cereals and which disperse by speirochory (i.e. accidental dispersal 
with seeds). The taxa dispersing together with a cultivated plant include the weeds of flax fields (Camelina alyssum subsp. alyssum, Cuscuta epilinum, and Spergula arvensis subsp. maxima), which are most likely extinct from the area of Poland (and perhaps even throughout their range).

The extinction or disappearance of these taxa is particularly dangerous, because they do not occur anywhere in natural communities. They have evolved as a result of selection by humans, so humans should now set about saving them.

\subsection{Synecological characteristics of threatened species}

Among the 74 species covered in this contribution, 58 are segetal weeds, 13 are ruderal plants, and 3 species occur in both types of habitats. The segetal weeds include first of all species from plant associations of the alliance Caucalidion platycarpi. In Poland they occur on soils with a higher calcium carbonate content: rendzinas, black soils, and alluvial soils along water courses. There are 19 species closely associated with this alliance, and 10 others occur mostly within it, but they manifest a broader ecological spectrum. The 4 species of weeds of flax fields occur in associations classified in the order Lolio remotae-Linetalia. The remaining weeds occur in various associations of the order Sperguletalia arvensis.

The archaeophytes occurring in ruderal sites are included in quite diverse classes. Coronopus procumbens and Sclerochloa dura occur in associations of the class Polygono arenastrii-Poetea annuae, on dry roadsides. Species like Solanum alatum and Chenopodium vulvaria occur in associations of the subclass Sisymbrietea. In drier and more xerothermic ruderal associations of the order Onopordetalia acanthii, species like Marrubium vulgare and Hyssopus officinalis occur.

Because of the fairly uniform synecological affiliation of most of the segetal weeds, they seem to be easier to protect or reintroduce. The species of archaeophytes liable to extinction require diversified habitats with specific requirements of soil type and ambient temperatures. Many of these are relics of cultivation, most often medicinal plants or spices, such as Marrubium vulgare and Hysopus officinalis mentioned above, or Parietaria officinalis and Anthriscus cerefolium var. cerefolium.

\subsection{Synthetic data on the distribution of endangered taxa}

The floristic database developed for the purposes of the Distribution atlas of vascular plants in Poland (Zając A. \& Zając M. 2001) was used here to generate combined maps for several groups of species (Fig. 2). In each cartogramme unit $(10 \mathrm{~km} \mathrm{x} 10 \mathrm{~km})$ of the ATPOL database (see http://www.ib.uj.edu.pl/en/), the

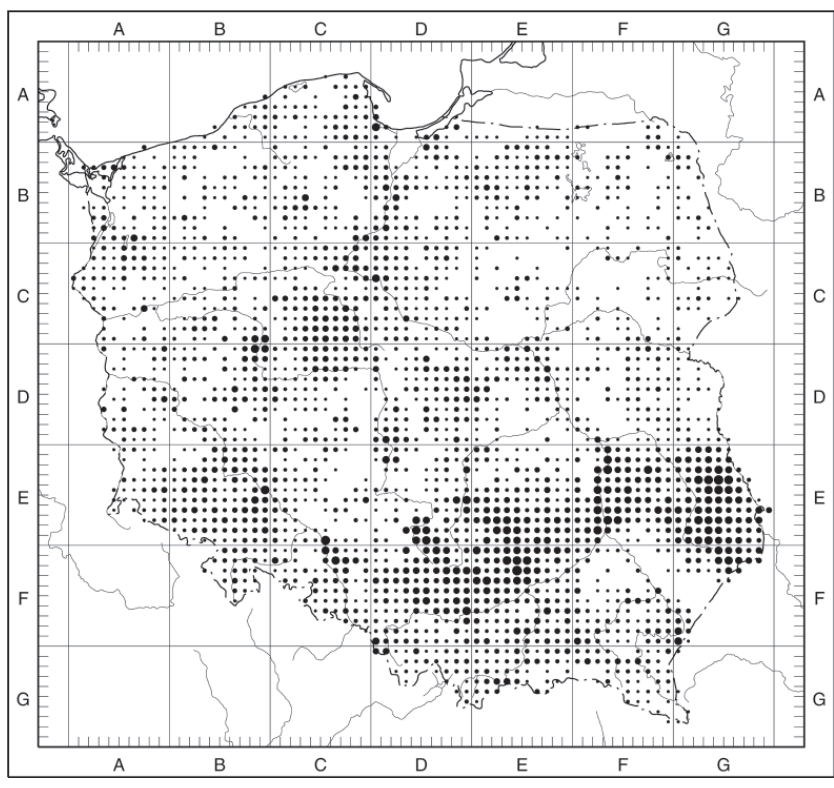

Fig. 2. Concentrations of segetal archaeophytes threatened with extinction in Poland, which occur in communities of the alliance Caucalidion platycarpi

diameter of circles represents the number of species of archaeophytes found in the unit. The most endangered and the largest group of the alliance Caucalidion platycarpi inhabits principally the uplands of southern Poland. In this region also the most endangered and rarest species show the highest level of fidelity to this syntaxon. There is also one more centre of their distribution, although less evidently marked, covering the central part of Greater Poland (Wielkopolska); namely the Kuyavia (Kujawy) region and the lower section of the Vistula river. However, the species occurring there have a wider distribution and are less characteristic for

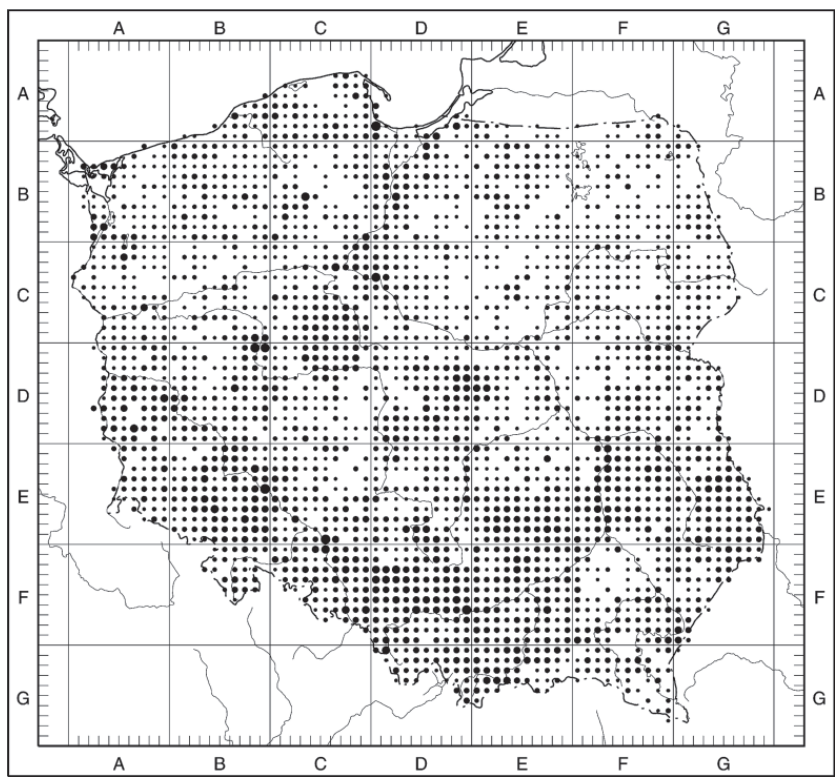

Fig. 3. Concentrations of segetal archaeophytes threatened with extinction in Poland, which occur in communities other than those belonging to Caucalidion platycarpi 
this alliance. The fact that the most valuable archaeophytes are confined to a certain part of Poland enhances the danger to this group, as the distribution of their joint occurrence is very limited.

The remaining segetal species (Fig. 3) still occur in larger areas and are absent only from north-eastern Poland and much rarer in the Western Pomeranian region. These species are mainly classified as vulnerable (V), thus less threatened with extinction.

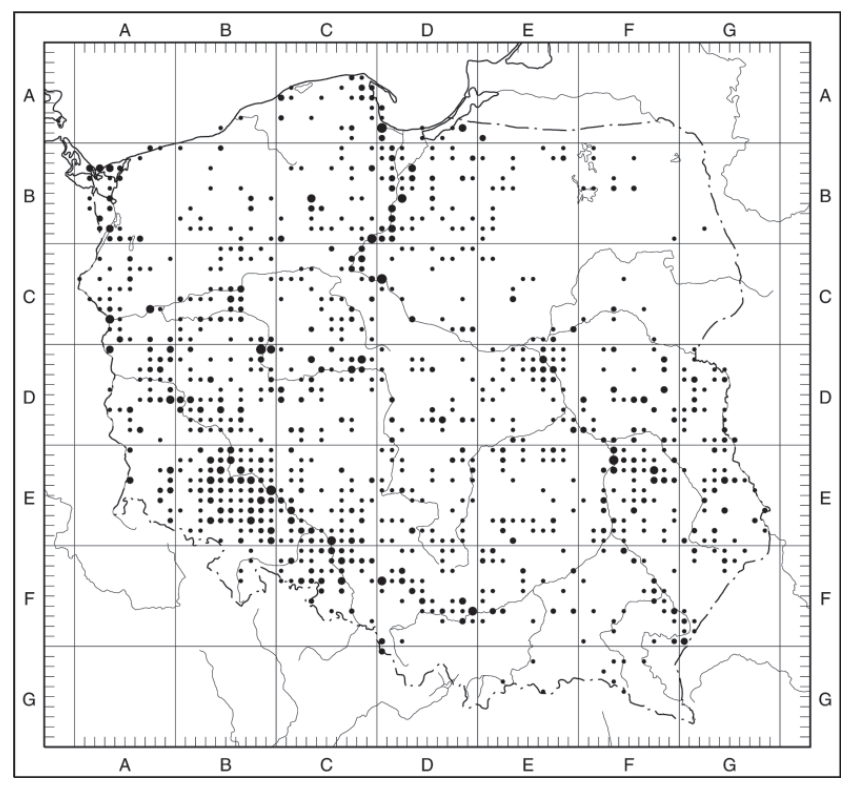

Fig. 4. Concentrations of ruderal archaeophytes threatened with extinction in Poland

The distribution of species associated with ruderal habitats is very interesting (Fig. 4). The highest concentration of their stations is found in Lower Silesia. In the remaining part of Poland they are associated with centres of the early settlement period, such as Kraków, Poznań, Toruń, Gdańsk, Puławy, and Lublin. The ruderal flora of these cities undergoes rapid modifications, so that habitats change and these species are almost equally divided into endangered (E) and vulnerable (V).

We did not consider here the group distributions of extinct weeds of flax fields, which once were dispersed throughout Poland, and 2 species of the genus Solanum (S. alatum and S. luteum) and 2 subspecies of Rhinanthus, for which the distribution maps in Poland have not been elaborated yet.

\subsection{Causes of extinction and ways to prevent it (restitution and reintroduction)}

The causes of the disappearance of species from segetal and ruderal habitats are complex and very different from each other. The segetal weeds found mainly in plant associations on soils richer in calcium carbonate are disappearing, chiefly because of seed cleaning and excessive use of chemicals in agriculture. The elimina- tion of specialised speirochorous species could be illustrated using the example of weeds of flax fields. These were adapted to traditional methods of seed cleaning, and the modern mechanical methods of cleaning eliminated them altogether. At present these weeds are extinct in Poland. A similar situation occurs with respect to many barochorous species (i.e. dispersed only by gravity), such as Conringia orientalis, Bupleurum rotundifolium, Nigella arvensis, and Vaccaria pyramidata, and species of the alliance Caucalidion platycarpi, which are speirochorous.

The disappearance of ruderal weeds is connected with the changes occurring in habitats, principally in cities, as it is demonstrated in their distribution map (Fig. 4). Cities in the past provided suitable living conditions for high numbers of these plants. The ruderal species that have vanished recently, are associated with sites rich in ammonia nitrogen, and with fertile soils rich in humus. This type of habitats is disappearing quickly. Town and cities have become cleaner, and anthropogenic soils usually contain there a high proportion of gravel, etc., which does not favour the development of such weeds.

In our opinion the only possibility of saving these disappearing archaeophyte species could be to reintroduce them in large numbers into habitats kept under constant supervision. Most of the diaspores can still be obtained from Polish plants. Perhaps a closer inspection of flax fields in north-eastern Poland may still reveal some weeds associated with flax (in the sowing material still cleaned by traditional methods).

The disappearing oldest segetal weeds - archaeophytes - should be reintroduced into substitute habitats. They may be saved by ex situ cultivation. The places suitable for such protective measures could include botanical gardens and open-air museums and preserved old buildings (parts of ethnographic parks).

Some botanical gardens in Poland are large (e.g. 64 ha in Łódź, 40 ha in Powsin near Warsaw, 22 ha in Poznań), so some weeds are cultivated on separate lots. Also open-air museums are usually quite large, preserving examples of old rural architecture, and are particularly well-suited as the sites to protect segetal weeds on special fields with cereal plants. If crop seeds with a high proportion of speirochorous weed diaspores are applied, and the remaining species are sown additionally into the soil, the segetal weeds can be effectively protected. Open-air museums can also be used to provide suitable habitats for ruderal weeds. These will only require more precise measures when preparing the substrate.

Open-air museums and botanical gardens are not uniformly located throughout Poland. If we get to know the distribution ranges and ecological requirements of various species, we can design ex situ cultivation in suitable sites with favourable climatic conditions. 


\section{Discussion}

Due to our growing knowledge about alien plant species in Poland, the lists for particular groups of anthropophytes can be modified. In this paper we present the list of endangered archaeophytes for Poland with some changes. For example, Hyssopus officinalis and Marrubium vulgare are included here, whereas previously they have been considered as kenophytes (=neophytes) (Zając at al. 1998; TokarskaGuzik 2005). In the last publication those species on the ground of historical sources were described as the "oldest" arrivals among kenophytes, present in the $16^{\text {th }}$ and $17^{\text {th }}$ century flora of Poland (Tokarska-Guzik 2005). As mentioned above, in the Polish Plant Red Data Book (Kaźmierczakowa \& Zarzycki 2001), only 6 species of archaeophytes were included, but their classification is similar to the one presented here. In the „Red List of Vascular Plants in Poland" (Zarzycki \& Szelagg 2006), 34 species of archaeophytes are included, but their classification is only partially similar to ours. Comparisons are difficult, because the first publication does not include the category critically endangered (CR). Because of this, the 2 categories (CR and EN) were considered jointly here. In most cases in the list presented here, the degree of threat is higher. It means that there is a need to verify our knowledge about the current distribution of archaeophytes, connected with both segetal and ruderal habitats, to assess the real degree of its threat. In our opinion, it is necessary to distinguish the category CR to show the most endangered group of species.

\section{Conclusions}

1. In Poland, more than 165 archaeophyte species have been identified. Out of this number, 74 are classified as extinct or disappearing: 5 extinct (EX), 13 critically endangered (CR), 16 endangered (EN), 5 vulnerable (VU), and 9 data-deficient (DD).

2. Among the disappearing archaeophyte species, special attention should be paid to those whose evolution has been assisted by humans and are classified as archaeophyta anthropogena. The total number of such species in Poland is 21, and as many as 18 of them are threatened.

3. The greatest number of endangered segetal weeds is found within associations of the alliance Caucalidion platycarpi, on soils rich in calcium carbonate.

4. The distribution of disappearing species of archaeophytes in Poland is not uniform. Their numbers are highest in the uplands of southern Poland. Ruderal species are most numerous in oldest cities and in Lower Silesia.

5. These species can be saved only by ex situ cultivation in botanical gardens and open-air museums. Entire communities of segetal weeds can be reconstructed and suitable conditions for ruderal species can be found there.

\section{References}

Čeřovský J., Feráková V., Holub J., Maglocký S. \& ProcházKa F. 1999. Red Data Book of Czech and Slovak republics. Vascular plants. 456 pp. Priroda, Bratislava.

IUCN REDLIST CATEGORIES. 1994. Prepared by the IUCN Species Survival Commission, Switzerland, 21 pp.

Kaźmierczakowa R. \& Zarzycki K. (eds.). 2001. Polska czerwona księga roślin. Paprotniki i rośliny kwiatowe, 2nd ed. 664 pp. PAN, Instytut Botaniki im. W. Szafera, Instytut Ochrony Przyrody, Kraków.

Kornaś J. \& Medwecka-Kornaś A. 2002. Geografia roślin, wyd. 2, 634 pp. Wyd. Nauk. PWN, Warszawa.

Kotiranta H, Uotila P, Sulkava S \& Peltonen S-L. 1998. Red Data Book of East Fenoscandia. Ministry of the Environment, Finnish Environment Institute \& Botanical Museum, Finnish Museum of Natural History, Helsinki.

Ludwig G \& Schnittler M (eds.). 1996. Rote Liste gefährdeter Pflanzen Deutschland. 744, XVI pp. Bundesamt für Naturschutz, Bonn, Bad Godesberg.
KUKKONEN I. 1995. What is an archaeophyte? ISKOS 5: 480488. Third Nordic Conference on the Application of Scientific Methods in Archaeology.

Mirek Z. 1981. Problemy klasyfikacji roślin synantropijnych. Wiad. Bot. 25(1): 45-54.

NikLfeld H. (ed.). 1999 Rote Listen gefährdeter Pflanzen Österreichs. 292 pp. Bundesministerium für Umwelt, Jungend und Familie, Graz.

Scholz H. 1995. Das Archaeophyten Problem in neuer Sicht. Schr.- R. f. Vegetationskunde 27: 431-439.

TоKARSKA-GuZIK B. 2005. The Establishment and Spread of Alien Plant Species (Kenophytes) in the Flora of Poland. Prace naukowe Uniw. Śląskiego w Katowicach 2372: 1-192.

ZająC A. 1978. Atlas of distribution of vascular plants in Poland (ATPOL). Taxon 27(5/6): 481-484.

ZAJẠC A. 1979. The origin of archaeophytes occuring in Poland. Rozprawy Habilitacyjne Uniwersyetu Jagiellońskiego (Cracow) 29: 1-219.

Zajac A. 1983. Studies on the origin of archaeophytes in Poland. Part I. Methodical consideration. Zeszyty 
Naukowe Uniwersytetu Jagiellońskiego. Prace Bot. (Cracow) 11: 87-107.

Zajac A. 1987a. Studies on the origin of archaeophytes in Poland. Part II. Taxa of Mediterranean and AtlanticMediterranean origin. Zeszyty Naukowe Uniwersytetu Jagiellońskiego. Prace Bot. (Cracow) 14: 7-50.

ZajĄC A. 1987b. Studies on the origin of archaeophytes in Poland. Part III. Taxa of Irano-Turanian, Euro-SiberianIrano-Turanian and Mediterranean-Irano-Turanian origin. Zeszyty Naukowe Uniwersytetu Jagiellońskiego. Prace Bot. (Cracow) 15: 93-129.

ZAJĄC A. 1988. Studies on the origin of archaeophytes in Poland. Part IV. Taxa of Pontic-Pannonian, MediterraneoSouth Asiatic, South Asiatic and Middle European origin, archaeophyta anthropogena, Archaeophyta resistentia, Archaeophytes of unknown origin. Zeszyty
Naukowe Uniwersytetu Jagiellońskiego. Prace Bot. (Cracow) 11: 87-107.

ZająC A. \& ZająC M. (eds.). 2001. Distribution Atlas of Vascular Plants in Poland. xii+714 pp. Edited by Laboratory of Computer Chorology, Institute of Botany, Jagiellonian University, Cracow.

Zając A., Zając M. \& ToKARsKa-GuZiK B. 1998. Kenophytes in the flora of Poland: list, status and origin. In: J. B. FALIŃSKi, W. AdAMOWSKi \& B. JaCkOWIAK (eds.). Synantropization of plant cover in new Polish research. Phytocoenosis 10 (N.S.) Suppl. Cartogr. Geobot. 9: 107-116.

ZARZYCKI K. \& SZELĄG Z. 2006. Red list of vascular plants in Poland. In: Z. Mirek, K. ZarZycki, W. WojewodA \& Z. Szeląg (eds.). Red list of plants and fungi in Poland, pp. 9-20. W. Szafer Institute of Botany, Polish Academy of Sciences, Kraków. 
Appendix. List of old synanthropic species (archaeophytes) endangered in Poland

\begin{tabular}{|c|c|c|c|}
\hline Categories of threat & Species & Habitat & Species origin \\
\hline \multirow[t]{5}{*}{ EX - Extinct } & Camelina alyssum subsp. alyssum & $\mathrm{S}$ & Aa \\
\hline & Cuscuta epilinum & $\mathrm{S}$ & $\mathrm{Aa}$ \\
\hline & Spergula arvensis subsp. maxima & $\mathrm{S}$ & $\mathrm{Aa}$ \\
\hline & Stachys arvensis & $\mathrm{S}$ & WM \\
\hline & Vaccaria pyramidata & $\mathrm{S}$ & AS \\
\hline \multirow{13}{*}{$\mathrm{CR}$ - Critically endangered } & Adonis flammea & S & MIT \\
\hline & Ajuga chamaepitys & S & M \\
\hline & Allium rotundum & $\mathrm{S}$ & $\mathrm{PH}$ \\
\hline & Caucalis daucoides & S & MIT \\
\hline & Chrysanthemum segetum & $\mathrm{S}$ & M \\
\hline & Conringia orientalis & S & MIT \\
\hline & Erysimum repandum & S & IT \\
\hline & Fumaria rostellata & $\mathrm{S}$ & $\mathrm{Pa}$ \\
\hline & Lolium remotum & S & $\mathrm{Aa}$ \\
\hline & Nigella arvensis & $\mathrm{S}$ & EM \\
\hline & Rhinanthus alecterolophus subsp. buccalis & S & Aa \\
\hline & Rhinanthus serotinus subsp. apterus & $\mathrm{S}$ & Aa \\
\hline & Scanadix pecten-veneris & S & MIT \\
\hline \multirow[t]{16}{*}{ EN - Endangered } & Anagallis foemina & S & M \\
\hline & Bupleurum rotundifolium & $\mathrm{S}$ & MIT \\
\hline & Chenopodium murale & $\mathrm{R}$ & M \\
\hline & Chenopodium opulifolium & $\mathrm{S}$ & [M?]-IT \\
\hline & Chenopodium urbicum & $\mathrm{R}$ & PIT \\
\hline & Chenopodium vulvaria & $\mathrm{R}$ & M \\
\hline & Coronopus procumbens & $\mathrm{S} / \mathrm{R}$ & $\mathrm{M}$ \\
\hline & Fumaria schleicheri & $\mathrm{S}$ & IT \\
\hline & Gagea arvensis & $\mathrm{S}$ & M \\
\hline & Galium tricorne & $\mathrm{S}$ & MIT \\
\hline & Herniaria hirsuta & $\mathrm{S}$ & MIT \\
\hline & Kickxia spuria & $\mathrm{S}$ & M \\
\hline & Linaria arvensis & $\mathrm{S}$ & M \\
\hline & Sclerochloa dura & $\mathrm{R}$ & MIT \\
\hline & Thymelaea passerina & $\mathrm{S}$ & MIT \\
\hline & Veronica opaca & S & Aa \\
\hline \multirow{31}{*}{ VU - Vulnerable } & Adonis aestivalis & S & MIT \\
\hline & Aethusa cynapium subsp. agrestis & S & Aa \\
\hline & Agrostemma githago & S & NM \\
\hline & Anthriscus caucalis & $\mathrm{R}$ & M \\
\hline & Anthriscus cerefolium var. cerefolium & $\mathrm{R}$ & $\mathrm{Aa}$ \\
\hline & Atriplex rosea & $\mathrm{R}$ & MP \\
\hline & Bromus arvensis subsp. arvensis & $\mathrm{S}$ & Aa \\
\hline & Bromus secalinus & S & $\mathrm{Aa}$ \\
\hline & Camelina microcarpa subsp. sylvestris & $\mathrm{S}$ & $\mathrm{Aa}$ \\
\hline & Camelina sativa & S & $\mathrm{Aa}$ \\
\hline & Chamomilla recutita & $\mathrm{S}$ & EM \\
\hline & Chenopodium ficifolium & $\mathrm{R}^{3}$ & $\begin{aligned} \text { Livi } \\
\text { IT }\end{aligned}$ \\
\hline & Euphorbia falcata & $\mathrm{S}$ & MIT \\
\hline & Fumaria vaillantii & S & IT \\
\hline & Hyssopus officinalis & $\mathrm{R}$ & M \\
\hline & Kickxia elatine & S & NM \\
\hline & Lathyrus tuberosus & S & PIT \\
\hline & Lolium temulentum & S & NM \\
\hline & Marrubium vulgare & $\mathrm{R}$ & PP \\
\hline & Melandium noctiflorum & $\mathrm{S}$ & $\mathrm{P}$ \\
\hline & Misopates orontium & $\mathrm{R} / \mathrm{S}$ & M \\
\hline & Neslia paniculata subsp. paniculata & $\mathrm{S}$ & $\mathrm{Aa}$ \\
\hline & Parietaria officinalis & $\mathrm{R}$ & $\mathrm{M}$ \\
\hline & Psium sativum subsp. arvense & $\mathrm{S}$ & $\mathrm{Aa}$ \\
\hline & Portulaca oleracea & $\mathrm{R} / \mathrm{S}$ & MIT? \\
\hline & Ranunculus arvensis & $\mathrm{S}$ & MIT \\
\hline & Silene gallica & S & WM \\
\hline & Stachys annua & S & PP \\
\hline & Valerianella rimosa & S & NM \\
\hline & Veronica agrestis & S & M \\
\hline & Veronica polita & $\mathrm{S}$ & MIT \\
\hline
\end{tabular}




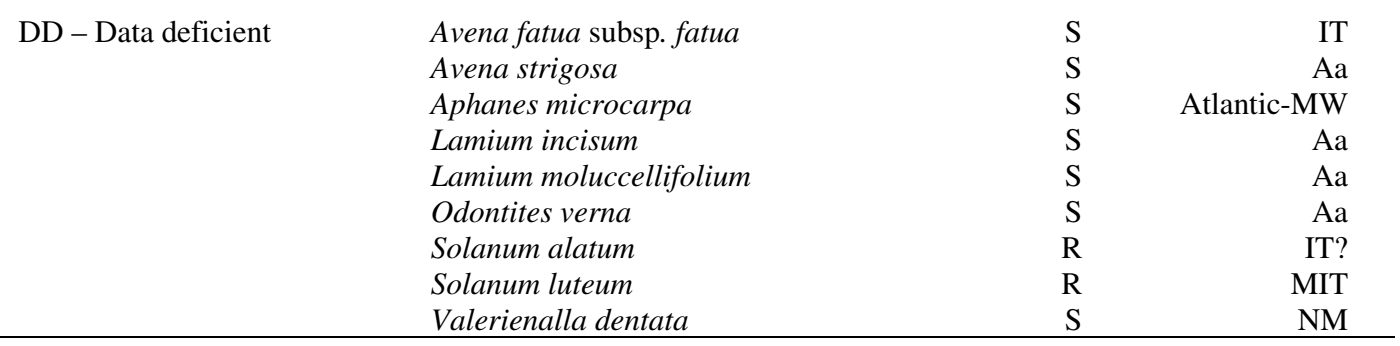

Explanations: Aa - archaeophyta anthropogena, AS - SE Asia \& subtropics, EM - E Mediterranean, IT - Irano-Turanian, M - Mediterranean, MIT Mediterranean-Irano-Turanian, MP - Mediterranean-Pannonian, NM - N Mediterranean, P - Pontic, Pa - Pannonian, PH - Ponto-Hyrcanian, PIT - PonticIrano-Turanian, PP - Pontic-Pannonian, R - ruderal species, S - segetal species, WM - W Mediterranean, ? - doubtful as an archaeophyte or of uncertain origin 